the discovery of the oxide also requires considerable revision. In referring to achievements of Black's students, the statement (p. 46) that "Smithson Tennant developed the backward Cambridge school" is misleading, as his contact with Cambridge as a teacher was very brief. Appointed professor of chemistry in May 1813, he apparently delivered only one course of lectures, in April and May 1814. These lectures-were probably excellent; but he died the next February on the Continent, where he had been for the preceding five months. As to the backwardness of Cambridge (presumably compared with Glasgow) at the time, this seems open to question, but I am unable to express an opinion based on enough study.

Partly in jest, one might say that the last three of the examples quoted give grounds for suspicion that respectable reverence for local gods has unwitingly influenced investigation and appraisement of their deeds. Be that as it may, every recorder of facts and their interpretations is liable to various psychological influences which he must guard against. This well-known fact should constantly be remembered, perhaps especially earnestly in these times.

It is hoped that the usefulness and charm of this book will be so widely recognized that future editions will be demanded. As well as corrections of textual errors, another desirable improvement would then be possible-in the indexes, where mentions of some persons in the text are not recorded, and those of others often only partially. There is something to be said for no index at all, rather than one having the air and intention of completeness which in fact it is far from achieving. A searcher relying on the latter kind may be denied information to be found, though with unnecessary difficulty, from reading the text.

Altogether, this is an indispensable text-book for students of the Cullen-Thomson period. Its price is moderate for the feast of knowledge and entertain. ment it affords.

L. F. GILbert

\section{UNITARY BIOLOGY}

\section{Cell and Psyche}

The Biology of Purpose. By Edmund W. Sinnott. (John Calvin MeNair Lectures.) Pp. ix +121. (Chapel Hill, N.C.: University of North Carolina Press ; London: Oxford University Press, 1950.) 16s. net.

DROF. E. W. SINNOT'T'S thoughtful and stimulating book is based on one forthright, far-reaching thesis. "The position which I wish to defend ... is briefly this: that biological organization (concerned with organic development and physiological activity) and psychical activity (concerned with behaviour and thus leading to mind) are fundamentally the same thing" (p. 48). "It is this organization . . . which, as experienced by the organism, I believe to be the simplest manifestation of what in man has become conscious purpose" (p. 53). Sinnott is, of course, not the first to make suggestions of this kind. Somewhat similar attempts to avoid a bifurca. tion of Nature by refusing to admit the existence of a dualism are found in philosophies as different as those of Whitehead, the Gestalt school and Marxism. Sinnott's characteristic contribution is that he approaches the subject as a student of development. His professional biological interests bring him into immediate contact with those processes in which a young organism is driven by its own internal constitution towards the realization of a specific end, the adult state-processes which strongly suggest a parallel with those carried out by man under the guidance of a conscious purpose. Thus, whereas most authors who have thought on these lines have been perhaps most interested in the problem of knowing, Sinnott is particularly concerned with the problem of will.

It would certainly seem that, if we are ever to transcend the defeatist dualism of the conventional outlook on biology, Sinnott has indicated the general direction in which to seek a way of bringing the subjective experience of purpose into relation with material events. There is no doubt that, particularly during embryonic development, biological systems do sometimes get into states which result in a tendency for change to occur in a definite direction. At present, the examples of such states about which we know most do not involve the fully differentiated nervous system, but more simple systems in earlier stages of development. There is, however, no reason to deny that similar situations of 'competence' might arise in the brain, and it would be to such conditions that Sinnott would look to find the physical basis of will.

After developing these ideas in the first two chapters, in the third Sinnott mentions briefly their relevance to some of the classical problems of philosophy. He attempts rather to show that his outlook may lead to a new formulation than to provide ready answers. Thus on p. 89 he writes, "The real issue in the problem of freedom is again the funda. mental character of biological organization, of what it is that sets up self-reguiating mechanisms in a living thing, and ultimately in the nervous system of man, and which thus creates purposes and fulfils them in action". This is hinting, surely, that there may be some close parallel between the 'spontaneous' formation of a purpose (that is, free will) and the sudden arising of a previously non-existent crystal order when two suitable types of molecular species happen to come together in a liquid-a bizarre thought, but perhaps not entirely unworthy of turning over in the mind. It is certainly a stimulating book.

C. H. WADDINGTON

\section{QUANTUM THEORY OF MOLECULES}

Structure of Molecules and the Chemical Bond By Y. K. Syrkin and M. E. Dyatkina. Translated and revised by M. A. Partridge and D. O. Jordan. Pp. ix +509 . (London: Butterworths Scientific Publica. tions, Ltd., 1950.) $63 s$.

LTHOUGH the quantum mechanical treatment A of atomic and molecular structure is now universally accepted, remarkably few monographs on the subject have yet appeared. This book, by Y. K. Syrkin and M. E. Dyatkina, has already achieved recognition in its original Russian version, and the appearance of an English translation is therefore an event of some interest. During translation, certain additions and revisions have been made, and the intention evidently has been to provide a comprehensive and authoritative account of the subject for Western readers. 